Submission ID: 43842

\title{
Modeling Hydrothermal Circulation During Formation of the Oil and Gas
} Deposits in Volcanogenic Structures

A. Kiryukhin* (Volcanology \& Seismology Institute FEB RAS), P.O. Voronin (Institute of Volcanology \& Seismology FEB RAS), O.O. Usacheva (Institute of Volcanology \& Seismology FEB RAS)

\section{SUMMARY}

TOUGH2/TOUGHREACT modeling used to reproduce possible hydrothermal circulation regimes during formation of oil volcanogenic reservoirs (Rogozhnikovsky oil rhyolite reservoir (West Siberia) and White Tiger oil granite reservoir (Vietnam)) and water-methane deposits in volcanogenic-sedimentary basins (Kshuksky (West Kamchatka) and Koryaksky-Avachinsky volcanogenic basin (East Kamchatka)). Mutnovsky hydrothermal system used as a referenced example. 
Моделирование гидротермальной циркуляции при формировании нефте-газовых месторождений в вулканогенных структурах

А.В. Кирюхин* (Институт вулканологии и сейсмологии ДВО РАН), П.О. Воронин (Институт вулканологии и сейсмологии ДВО РАН), О.О. Усачева (Институт вулканологии и сейсмологии ДВО РАН)

\section{Введение}

С использованием TOUGH2/TOUGHREACT моделирования рассматриваются возможные режимы гидротермальной циркуляции при формировании нефтяных вулканогенных резервуаров (на примере Рогожниковского нефтяного риолитового резервуара (Зап. Сибирь), нефтяного резервуара в гранитах Белый Тигр (Вьетнам)) и водно-метановых залежей в вулканогенных бассейнах (на примере Кшукского месторождения (Зап. Камчатка) и КорякскоАвачинского вулканогенного бассейна (Камчатка)). Мутновская гидротермальная система используется в качестве референсного эталона.

\section{Рогожниковский нефтяной вулканогенный резервуар}

Механизм образования продуктивных резервуаров в риолитах рассматривается на примере Рогожниковского вулканогенного нефтяного резервуара (Зап. Сибирь) и объясняется в терминах TOUGHREACT-моделирования (Xu et al, 2006) длительной гидротермальной циркуляцией с химическим взаимодействием вода-порода, что приводит к увеличению проницаемости-пористости вдоль высокотемпературных потоков и заканчивается окончательным самозапечатыванием сформированного продуктивного резервуара (Кирюхин и др., 2013). Наблюдаемые в настоящее время давление, температура, фазовые условия, распределение проницаемости-пористости, химический состав флюидов и предполагаемый минеральный состав начальной породы (вулканическое стекло) используются как исходные данные для последующего TOUGHREACT-моделирования. Моделирование Рогожниковского резервуара на упрощенной прямоугольной модели 500x $500 \times 400 \mathrm{~m}^{3}$, состоящей из 100 элементов, показывают, что длительная гидротермальная циркуляция приводит к увеличению пористости (х 2.64) и проницаемости (х 50) благодаря замещению исходного вулканического стекла кварцем, альбитом и К-полевым шпатом; ранняя стадия гидротермальной циркуляции ( $<10$ тыс лет) отмечается кипением и значительным падением давления, а заключительная стадия характеризуется значительным отложением кальцита в основании восходящего потока, после чего происходит самозапечатывание резервуара. Это показывает возможность образования продуктивных резервуаров благодаря преобразованию исходного минерального состава в риолитах, вызванному гидротермальной циркуляцией, обнаруживают условия кратковременного падения давления на ранней стадии формирования резервуара (что благоприятно для привлечения нефти и рудообразующих флюидов в резервуар). Самозапечатывание резервуара на последней стадии гидротермальной циркуляции благоприятно для аккумуляции и удерживания флюидов в продуктивном резервуаре и формирования месторождений полезных ископаемых. Для более детального анализа Рогожниковского нефтяного резервуара разработана 3D TOUGHREACT модель, описывающая его реальную геометрию в области размерами 5.5х6 км², состоящая из 672 активных элементов. В этой модели гидротермальная проработка резервуара рассматривается при расходе восходящего потока теплоносителя 720 кг/с и энтальпии 1530 кДж/кг $\left(320^{\circ} \mathrm{C}\right)$ на интервале времени 0-2 млн. лет. Результаты моделирования в целом подтверждают полученный ранее на упрощенной модели механизм образования продуктивных резервуаров в вулканогенных породах риолитового состава, закономерности изменения эволюции термогидродинамического режима, фильтрационно-емкостных свойств и ассоциаций вторичных гидротермальных минералов (рис. 1). 



Рисунок 1 Возрастание температуры и паронасыщения (верхний рисунок) и увеличение пористости с 0.17 (начальное значение) до 0.27 (нижний рисунок) в результате гидротермальной ииркулящии с притоком глубинного теплоносителя $720 \mathrm{\kappa} / \mathrm{c}$ при его энтальпии 1530 кДж/кг спустя 500 лет после начала гидротермальной циркуляции.

\section{Нефтяное месторождение в гранитном массиве Белый Тигр (Вьетнам)}

Перераспределение нефти в гранитных интрузиях рассматривается с использованием TOUGH2 - T2VOC-моделирования (Falta et al, 1995). Показана возможность устойчивого концентрирования нефтяной фазы в верхней части нефте-пароконденсатного гидротермального резервуара за счет транспорта нефтяной компоненты в верхнюю часть разреза в газовой фазе с последующим удалением водной составляющей за счет нисходящего потока водной фазы в диапазоне температур $240-285^{\circ} \mathrm{C}$ и давлений $63.5-69.5$ бар (механизм вертикальной тепловой трубы с разнонаправленной циркуляцией газовой и жидкой фаз при прогреве снизу) (Кирюхин и др., 2015). При последующем остывании, масса нефтяной фазы значительно увеличивается за счет конденсации нефти из газовой фазы. В частности, на 
модели размерами 1 км х 1 км $^{2}$ с петрофизическими и фильтрационно-емкостными параметрами близкими к гранитному массиву нефтяного месторождения Белый Тигр (Вьетнам) и начальным равновесным распределением нефтяной компоненты в трех фазах (водной $\mathrm{Sw}=0.4$, газовой $\mathrm{Sg}=0.699$ и нефтяной $\mathrm{So}=0.001$ ) в результате пароконденсатной переработки по механизму тепловой трубы в верхней части разреза формируется устойчивая линза с нефтяной фазой мощностью 80 м $(\mathrm{So}=0.6)$ и массой 2.00 млн. тонн. При последующем остывании до $90-115^{\circ} \mathrm{C}$ и естественном заводнении нижней части разреза, масса нефтяной фазы увеличивается до 3.49 млн. тонн за счет конденсации нефти из газовой фазы. Предложенный и подтвержденный моделированием механизм формирования нефтяной залежи в гранитном фундаменте месторождения Белый Тигр в результате вертикальной восходящей миграции нефтяной фазы в пароконденсатных условиях в составе высокотемпературного флюида соответствует минералого-петрографическим особенностям коллекторских зон, химическому составу воднорастворимых нефтей фундамента, гидрохимической зональности и химическому составу подземных вод месторождения Белый Тигр.

\section{Водно-метановые залежи в вулканогенно-осадочных бассейнах Камчатки}

Показано, что зоны внедрения магмы, питающей Корякский и Авачинский вулканы фиксирующиеся по микросейсмическим данным в диапазоне глубин $-6.0 \div+2.0$ км абс. и $-1.5 \div$ +2.5 км абс., соответственно сопряжены с водно-метановыми резервуарами, которые примыкают к магматическим резервуарам вулканов с юго-востока и юго-запада, площадь потенциального накопления метана со значительными газовыми ресурсами оценивается в 650 км$^{2}$ (Кирюхин А.В. и др., 2015). Формирование газовых залежей под вулканами может происходить в результате геомеханического и термического воздействия магмы на вмещающие вулканогенно-осадочные породы, содержащие органическое вещество различного происхождения.

На разрезах Кшукского водно-метанового месторождения (Зап. Камчатка) хорошо просматриваются особенности распределения газонасыщенных резервуаров (Кирюхин и др., 2015): (1) Повсеместное массивное распространение газоносности в нижней части Этолонской свиты и в кровле подстилающих ее формаций; (2) Локальное массивное распределение газоносности в Эрмановской свите, форма газоносного резервуара напоминает трубу, которая могла унаследовать геометрию каналов вулканического аппарата или гидротермальной системы. Восходящая циркуляция подтверждается также положительными аномалиями 3D распределения давления и температуры $\left(102^{\circ} \mathrm{C}\right.$ на абс. отм. -2500 м). Естественно предположить, что при восходящей циркуляции газонасыщенных флюидов газовой фазой заполняются более проницаемые резервуары в зонах восходящих потоков. Сквозная циркуляция газонасыщенных флюидов подтверждается однородным изотопным составом $\delta^{13} \mathrm{C}$ метана $(-38 \%$ - $-36,9 \%)$, этана $(-25,8 \%$ - $-25,6 \%)$ и $\mathrm{CO}_{2}(-33,1 \%$ - $30,7 \%$ в в диапазоне глубин 1100 - -2500 м абс), что характерно для газогенерации метана в зонах повышенных температур. Доля потенциально газонасыщенных резервуаров (определенных по сейсмическому атрибуту Variance) в общем объеме Этолонского целевого горизонта

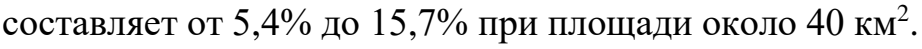

\section{Мутновский высокотемпературный геотермальный резервуар}

Опыт эксплуатации Мутновского геотермального месторождения (Камчатка) может быть использован не только при освоении других крупных геотермальных месторождений КурилоКамчатского региона, но и для понимания условий гидротермальной циркуляции, распределения проницаемости и температуры в высокотемпературных гидротермальных системах, структуры которых могут впоследствии использоваться для накопления углеводородов. Основные особенности условий формирования Мутновского геотермального месторождения (Кирюхин и др., 1993, 1991, 2002): 1. Приуроченность зон продукции к контактовой зоне интрузии в диапазоне температур 200-300 ${ }^{\circ} \mathrm{C} ; 2$. Гидравлическая связь Мутновского вулкана (область водного питания) и продуктивного геотермального резервуара, 
прилегающих фумарольных полей и горячих источников (область разгрузки парогидротерм); 3. Тепловое питание продуктивного геотермального резервуара осуществляется за счет инжекций магмы на абс. отметках $-4--7$ км, определяемых плоско-ориентированными кластерами локальных землетрясений.

\section{Заключение}

Механизм образования продуктивных резервуаров в риолитах объясняется в терминах TOUGHREACT-моделирования длительной гидротермальной циркуляцией с химическим взаимодействием вода-порода, что приводит к увеличению проницаемости-пористости вдоль высокотемпературных потоков и заканчивается окончательным самозапечатыванием сформированного продуктивного резервуара. Условия кратковременного падения давления на ранней стадии формирования резервуара благоприятны для привлечения нефти и рудообразующих флюидов. Самозапечатывание резервуара на последней стадии гидротермальной циркуляции благоприятно для аккумуляции и удерживания флюидов в продуктивном резервуаре. Аккумуляции нефтяной фазы в в верхних частях разреза способствуют пароконденсатные условия. Формирование водно-метановых залежей наблюдается в районах современного вулканизма в условиях восходящей гидротермальной циркуляции и в зонах термоконтактового взаимодействия магматических питающих систем активных вулканов с вмещающими вулканогенно-осадочные породами, содержащими органическое вещество различного происхождения.

Работа выполнена при поддержке РНФ по проекту 16-17-10008.

\section{Библиография}

1. Кирюхин А.В., Делемень И.Ф., Гусев Д.Н. Высокотемпературные гидротермальные резервуары, М. Наука 1991, 160 с.

2. Кирюхин А.В. Моделирование эксплуатации геотермальных месторождений // Владивосток, Дальнаука, 2002, 216 с.

3. Кирюхин А.В., Шадрина С.В., Пузанков М.Ю. Моделирование термогидрогеохимических условий формирования продуктивных резервуаров в вулканогенных породах // «Вулканология и сейсмология», 2013, № 2, с. 90-104.

4. Кирюхин А.В., Киреева Т.А. Формирование нефтяного резервуара в условиях пароконденсатной гидротермальной системы (по результатам численного моделирования на примере месторождения Белый Тигр, Вьетнам). «Геология нефти и газа», \#1, 2015 г., с.78-86.

5. А.В. Кирюхин, Ю.Ф. Манухин, С.А. Федотов, В.Ю. Лаврушин, Т. В. Рычкова, Г.В. Рябинин, А.Ю. Поляков, П.О. Воронин. Геофлюиды Авачинско-Корякского вулканогенного бассейна, Камчатка. «Геоэкология. Инженерная Геология. Гидрогеология. Геокриология. №4. 2015. с. 306-320.

6. Кирюхин А.В., Воронин П.О., Корзун Н.И. Водно-метановые резервуары вулканогенных бассейнов. Сборник КГТУ, 2015, с.23-33. DOI: 10.17217/2079-0333-2015-31-2333.

7. Falta R., Pruess K., Finsterle S., Battistelli A. T2VOC User's Guide LBNL-36400,1995,158

p.

8. Kiryukhin A.V. High temperature fluid flows in the Mutnovsky hydrothermal system, Kamchatka // Geothermics, Vol.23, No.1, 1993, p.49-64.

9. Pruess K., Oldenburg C., Moridis G. 1999. TOUGH2 User's Guide, Version 2.0. Rep. LBNL43134, Lawrence Berkeley Natl. Lab., Berkeley, California.

10. Xu T., Sonnenthal E., Spycher N., Pruess K. TOUGHREACT User's Guide: A Simulation Program for Nonisothermal Multiphase Reactive Geochemical Transport in Variably Saturated Geologic Media // LBNL-55460. 2006. 206 p. 


\section{References}

1. Kiryukhin A.V., Delemen I.F., Gusev D.N. High Temperature Hydrothermal Reservoirs, Moscow, Nauka 1991, 160 p (in Russian).

2. Kiryukhin A.V. Modeling of Exploitation of Geothermal Fields // Vladivostok, Dalnauka, 2002, 216 p. (in Russian).

3. Kiryukhin A. V., Shadrina S. V., and Puzankov M. Yu. Modeling the Thermohydrogeochemical Conditions for the Generation of Productive Reservoirs in Volcanogenic Rocks // Journal of Volcanology and Seismology, 2013, Vol. 7, No. 2, pp. 170-183.

4. Kiryukhin A., Kireeva T.. Formation of oil reservoir in hydrothermal steam-condensate conditions (modeling of the oil deposit White Tiger, Viet Nam). «Oil and Gas Geology», \#1, 2015, c.78-86 (in Russian).

5. Kiryukhin A., Manukhin Y., Fedotov S., Lavrushin V., Rychkova T., Ryabinin G., Polyakov A., Voronin P.. Geofluids of Avachinsky-Koryaksky Volcanogenic Basin, Kamchatka, Russia. II Geoecology. Engineering Geology. Hydrogeology. Geocriology. \#\#4. 2015. p. $306-320$ (in Russian).

6. Kiryukhin A.V., Voronin P.O., Korzun N.I. Water-methane reservoirs in Volcanogenic Basins. Proc. Kamchatka State Technical University, 2015, p.23-33. DOI: 10.17217/2079-03332015-31-23-33 (in Russian).

7. $\quad$ Falta R., Pruess K., Finsterle S., Battistelli A. T2VOC User's Guide LBNL-36400,1995,158 p.

8. Kiryukhin A.V. High temperature fluid flows in the Mutnovsky hydrothermal system, Kamchatka // Geothermics, Vol.23, No.1, 1993, p.49-64.

9. Pruess K., Oldenburg C., Moridis G. 1999. TOUGH2 User's Guide, Version 2.0. Rep. LBNL43134, Lawrence Berkeley Natl. Lab., Berkeley, California.

10. Xu T., Sonnenthal E., Spycher N., Pruess K. TOUGHREACT User's Guide: A Simulation Program for Nonisothermal Multiphase Reactive Geochemical Transport in Variably Saturated Geologic Media // LBNL-55460. 2006. 206 p. 